\title{
Strategi Perlawanan Venezuela dalam Menghadapi Tekanan Amerika Serikat melalui ALBA Tahun 2015-2017
}

\author{
Faradilla Firdaus \\ Universitas Airlangga
}

\begin{abstract}
ABSTRAK
Krisis ekonomi dan krisis kemanusiaan yang terjadi di Venezuela semenjak tahun 2014 menyebabkan Venezuela berada dalam tekanan internasional, terutama Amerika Serikat.Tekanan dari Amerika Serikat tersebut membuat Venezuela terisolasi dalam kawasan Amerika Latin maupun internasional. Dalam melawanan tekanan Amerika Serikat tersebut Venezuela kemudian memanfaatkan posisinya dalam ALBA sebagai regional power. Sebagaimana negara ALBA masih menunjukkan dukungan kuat terhadap Venezuela meskipun negara tersebut sedang dilanda krisis yang disinyalir karena kegagalan sistem perekonomian sosialis pada era Hugo Chavez.Penelitian ini kemudian menggunakan instrumen analisis teori kooperatif hegemoni yang menghasilkan tiga strategiyang dilakukanoleh Venezuelayaitu:(1) strategireduksibalancing dengan meningkatkan balance of fear terhadap Amerika Serikat; (2) strategi peningkatan bandwagoning terhadap negara anggota ALBA untuk mempertahankan eksistensi diskurs suportif kawasan; (3) agregasi power terhadap negara anggota ALBA untuk mencegah terjadinya defection dalam kawasan.
\end{abstract}

Kata Kunci: Tekanan kekuatan eksternal, balance of fear, bandwagoning, diskurs suportif kawasan, agregasi power, defection

Economic and humanitarian crisis that happened in Venezuela since 2014 has left Venezuela in international pressure, especially from the United States. United States pressure make Venezuela position's isolated in Latin America region also in international. In order facing United States pressure, Venezuela takes advantage of its position in ALBA as a regional power. As ALBA member countries still showing strong support towards Venezuela despite Venezuela is hit by crisis allegedly due to the failure of socialist economic system on Hugo Chavez's era. This research use hegemony cooperative theory as analysis instrument which is result three strategies by Venezuela: (1) balancing reduction strategy by increase balance of fear towards United States; (2) increasing bandwagoning strategy towards ALBA member countries to maintain the exsistence of regional supportive discourse; (3) aggregation power strategy towards ALBA member countries to prevention defection in the region.

Keywords: External power pressure, balance of fear, bandwagoning, regional supportive discourse, power aggregation, defection 


\section{Pendahuluan}

Paska turunnya Hugo Chavez dari kursi kepresidenan Venezuela di tahun 2013, Venezuela dibawah pimpinan Nicolas Maduro diguncang krisis politik dan ekonomi yang juga menyebabkan terjadinya krisis kemanusiaan. Kondisi tersebut cukup memprihatinkan lantaran mengingat pada dekade sebelumnya yaitu tepatnya pada pemerintahan Chavez, Venezuela merupakan salah satu negara di Amerika Latin yang memiliki kondisi perekonomian cukup baik bahkan merupakan salah satu regional power yang diperhitungkan di Amerika Latin maupun di dunia. Buruknya perekonomian Venezuela ini dapat dilihat dari GDP Venezuela dalam beberapa tahun terakhir yang mengalami penurunan sekitar $8,4 \%$. Kondisi tersebut merupakan jumlah GDP terendah jika dibandingkan dengan negara-negara besar di Amerika Latin seperti Argentina dan Mexico. Pada tahun 2014 hingga 2017 Venezuela mengalami inflasi yang mencapai prosentase sekitar 100\% hingga 600\%. Selain itu terjadi juga defisit anggaran negara sekitar $14 \%$ yang merupakan prosentase tertinggi di dunia serta tingkat pengangguran di Venezuela juga tercatat naik sekitar 20\% dari tahun 2012 (Worstall 2016).

Krisis politik dan ekonomi yang mendorong terjadinya krisis kemanusiaan di Venezuela membuat Venezuela berada dalam tekanan dari Amerika Serikat.Terdapat dua bentuk tekanan yang diberikan oleh Amerika Serikat, yaitu tekanan secara bilateral dan melalui pendekatan regional. Pada tekanan secara bilateral, Amerika Serikat merespon krisis kemanusiaan yang terjadi di Venezuela dengan mengeluarkan sanksi pertama yaitu Executive Order 13.692 karena menilai krisis tersebut telah menimbulkan ancaman bagi keamanan nasional dan kebijakan luar negeri Amerika Serikat (National Archives 2015). Selanjutnya pada era pemerintahan Donald Trump, Trump menekan Venezuela dengan dua cara yaitu: (1) ancaman intervensi militer yang diumumkan Trump pada sidang Dewan Keamanan PBB 11 Agustus 2017; (2) pembaharuan Executive Order 13.692 yang berisikan larangan segala bentuk transaksi dengan pemerintahan Venezuela dan perusahaan minyak Venezuela, Petroleos de Venezuela, S.A. (PDVSA) (Casey 2017; White House 2017). Sedangkan melalui pendekatan regional, semenjak tahun 2015 Amerika Serikat telah mendesak organisasi regional Organization of American States (OAS) untuk memberlakukan sanksi yang lebih tegas terhadap pemerintahan Maduro terkait krisis kemanusiaan yang terjadi di Venezuela. 
Hasilnya pada tahun 2016, Sekertaris Jendral OAS Luis Almagro meminta komunitas internasional untuk meningkatkan sanksi kepada pemerintahan Maduro dan meminta Venezuela menandatangani Inter-America Democratic Charter sebagai dasar dari proses alterasi pengaturan Undang-Undang tentang demokrasi di Venezuela (Pedraza 2016).

Meskipun dibawah tekanan internasional karena krisis kemanusiaan, pemerintahan Maduro tetap bersikeras menolak bahwa Venezuela saat ini sedang berada dalam kondisi krisis kemanusiaaan dan mengklaim bahwa Amerika Serikat yang berada dibalik kekacauan ekonomi Venezuela. Hal ini seperti yang ditegaskan oleh Delcy Rodriguez, Ketua Dewan Konstituen Nasional (ANC) dan Mantan Menteri Luar Negeri Venezuela bahwa tidak ada krisis humanitarianisme di Venezuela. Venezuela memiliki mode inklusi sosial yang berbeda dalam mengatasi permasalahan kemiskinan dan kelaparan (Al-Jazeera 2017). Ironisnya dalam ketergabungannya pada organisasi regional ALBA (Bolivarian Alliances for the Americans), Venezuela merupakan salah satu pelopor dari organisasi tersebut dan memegang peran kunci didalamnya. ALBA yang merupakan organisasi regional bentukan Presiden Venezuela Hugo Chavez pada tahun 2004 dengan tuuan untuk mengadvokasi pembangunan negara-negara Amerika Latin dan Karibia yang pertumbuhannya masih terbelakang dan memiliki sedikit sekali kontribusi pada pertumbuhan kawasan, bisa dilihat pada Tabel 1. (Tarris \& Azzi 2011).

\section{Tabel 1. Populasi Luas Lahan dan Total GDP Negara Anggota ALBA Tahun 2014}

\begin{tabular}{|c|c|c|c|}
\hline Negara & Populasi & $\begin{array}{c}\text { Luas Lahan } \\
\left(\mathbf{k m}^{\mathbf{}}\right)\end{array}$ & $\begin{array}{c}\text { GDP } \\
\text { (US\$ Million ) }\end{array}$ \\
\hline $\begin{array}{c}\text { Antigua dan } \\
\text { Barbuda }\end{array}$ & 85,632 & 442 & $1,280.13$ \\
\hline Bolivia & $9,119,152$ & $1,098,581$ & $32,996.19$ \\
\hline Kuba & $11,451,652$ & 110,861 & $80,656.10$ \\
\hline Dominika & 72,660 & 754 & $65,231.03$ \\
\hline Ekuador & $14,573,101$ & 256,370 & $101,726.33$ \\
\hline Grenada & 109,590 & 348 & 911.48 \\
\hline Nikaragua & $5,891,199$ & 129,495 & $11,880.44$ \\
\hline $\begin{array}{c}\text { Saint Kitts dan } \\
\text { Nevis }\end{array}$ & 51,538 & 261 & 847.78 \\
\hline
\end{tabular}




\begin{tabular}{|c|c|c|c|}
\hline Saint Lucia & 180,870 & 617 & $1,551.92$ \\
\hline $\begin{array}{c}\text { Saint Vincent } \\
\text { dan } \\
\text { Grenadines }\end{array}$ & 120,000 & 389 & 727.23 \\
\hline Venezuela & $28,199,825$ & 916,445 & $482,359.32$ \\
\hline Total ALBA & $\mathbf{6 9 , 5 1 3 , 2 2 1}$ & $\mathbf{2 , 5 1 3 , 3 3 7}$ & $\mathbf{7 2 0 , 1 6 7 . 9 5}$ \\
\hline
\end{tabular}

(Sumber: World Bank 2018)

Ditengah posisinya yang terhimpit oleh tekanan Amerika Serikat, Venezuela kemudian melakukan strategi perlawanan melalui ALBA dengan Venezuela yang memanfaatkan posisinya sebagai regional power di kawasan tersebut. Adapun strategi perlawanan yang dilakukan Venezuela melalui ALBA ini dianalisa melalui teori kooperatif hegemoni yaitu dengan menguatkan aliansi dalam ALBA.

\section{Strategi Kooperatif Hegemoni terhadap Negara Kawasan dalam Mempertahankan Diri terhadap Tekanan Eksternal}

Strategi kooperatif hegemoni berangkat dari pendekatan ideational institutional realism yang melihat keterbatasan geopolitik negara dalam sistem internasional bukan sebuah hal yang negatif melainkan sebagai alasan agar negara dapat menggabungkan ide-ide kausal dan keyakinan bersama melalui kerjasama (Pedersen 2002). Terdapat tiga strategi utama dalam teori kooperatif hegemoni. Pertama, kapasitas agregasi power yaitukapasitas negara core untuk melibatkan negara peripheral dalam proyek politik kawasan yang dipengaruhi oleh faktor unipolaritas kawasan, distribusi power yang ditentukan oleh derajat asimetris dan konsetelasi faktor eksternal. Kedua, kapasitas power-sharing yaitu kapasitas pembagian power oleh negara core terhadap peripheral, yang dipengaruhi oleh empat hal antara lain balance of fear, kepercayaan prinsipal, kepercayaan kausal dan polity structure. Ketiga, kapasitas komitmen yang dipengaruhi oleh empat hal: (1) biaya non komitmen yang bergantung pada geopolitik, geoekonomi, interdependensi dan persepsi negara; (2) pengaturan konstitusional dan memfasilitasi prosedur partisipasi dalam integrasi regional; (3) kepentingan negara core itu sendiri; (4) eksistensi diskursus suportif (Pedersen 2002).

Secara spesifik strategi kooperatif hegemoni bertujuan mereduksi proses balancing serta meningkatkan bandwagoning dengan negara-negara kawasan. Hal ini mengimplikasikan pada tiga 
hal (sesuai dengan tiga strategi kooperatif hegemoni yang telah disebutkan) yaitu: (1) negara core melakukan agregasi power dengan negara core bersedia membiayai side payments dari kerjasama yang dilakukan dalam organisasi regional dengan tujuan untuk mencegah negara peripheral melakukan proses defection dalam institusi regional; (2) reduksi balancing yang dilakukan melalui strategi power-sharing antara negara core dengan negara peripheral. Reduksi balancing dilakukan dengan melakukan identifikasi terhadap nilai-nilai kawasan yang bertujuan untuk mendorong proses integrasi melalui pembangunan komunitas kawasan. Pereduksian balancing kemudian mendorong negara core bertindak sebagai regional defendersyang menganggap bahwa kekuatan eksternal dapat mempengaruhi perubahan nilai-nilai kawasan sehingga dapat meningkatkan legitimasi posisi negara core sebagai regional power. Dalam artian, saat proses reduksi balancing yang dipengaruhi oleh kekuatan eksternal elemen balance of fear merupakan elemen terpenting dalam strategi kooperatif hegemoni; (3) strategi kooperatif hegemoni akan mengikat negara peripheral dalam struktur yang ada di kawasan sehingga meningkatkan bandwagoning kawasan dan memunculkan diskursus suportif sebagai bagian dari komitmen dalam organisasi kawasan (Pedersen 2002). Berdasar penjelasan tersebut dapat ditarik pemahaman bahwasanya dalam mempertahankan status quo dan dukungan regional, setidaknya negara core menerapkan tiga strategi. Pertama dengan menaikkan balance of fear, meningkatkan bandwagoning, dan menaikkan power serta komitmen untuk mencegah proses defection dalam organisasi regional.

\section{Strategi Reduksi Balancing Venezuela dengan Negara Anggota ALBA melalui Peningkatan Balance of Fear terhadap Amerika Serikat}

Venezuela memanfaatkan posisinya yang terhimpit oleh tekanan Amerika Serikat untuk meningkatkan balance of fear negara ALBA terhadap Amerika Serikat. Hal ini pertama kali tercermin dalam surat terbuka yang dituliskan oleh Maduro kepada warga negara Amerika Serikat dengan menegaskan bahwa Venezuela bukan ancaman bagi negara manapun justru Venezuela menganggap sikap Amerika Serikat yang mengeluarkan Executive Order 13.692 merupakan ancaman bagi Venezuela beserta negara Amerika Latin dan Karibia lainnya. Dalam surat yang diterbitkan dalam surat kabar The New York Times pada 17 Maret 2015, terdapat setidaknya tiga 
poin yang menyebutkan bahwa Amerika Serikat adalah ancaman bagi negara Amerika Latin dan Karibia terutama negara ALBA antara lain yaitu: (1) Amerika Serikat dianggap tidak adil dan tidak menghormati Piagam Perdamaian Community of Latin American and Caribbean States (CELAC) dan piagam perdamaian internasional; (2) sikap Amerika Serikat menurut Maduro mengingatkan kembali kepada sejarah kelam hubungan Amerika Serikat dengan masyarakat Amerika Latin dan Karibia; (3) Maduro menilai Executive Order 13,692 telah melanggar prinsip kedaulatan dalam piagam PBB (Ministerio del Poder Popular Para Relaciones Exteriores 2015).

Tidak lama setelah surat terbuka tersebut dikeluarkan, pada pertemuan luar biasa ke-4 ALBA tanggal 11 Agustus 2015 Venezuela mengklaim bahwa Amerika Serikat berusaha melakukan sabotase ekonomi Venezuela melalui vulture plan atau vulture funds. Pada pertemuan tersebut, Maduro menyatakan rasa keterancaman Venezuela dengan memaparkan bukti yaitu berupa laporan dari Kementerian Luar Negeri Venezuela jika pemerintah Amerika Serikat memerintahkan Kedutaan Besar Amerika Serikat di Caracas untuk mengaplikasikan vulture plan (ALBA-TCP 2015). Namun setelah menolak penerapan vulture fund dan kehadiran vulture investor pada tahun 2015 dan 2016 dengan bergantung pinjaman kepada Tiongkok, pada 3 November 2017 Maduro mengumumkan bahwa Venezuela sudah tidak lagi dapat membayar hutang luar negerinya. Maduro dalam pidatonya menyatakan bahwa pemerintah Venezuela dan PDVSA akan berusaha untuk merestrukturisasi pembayaran hutang tersebut dengan melakukan pembayaran hutang sekitar US\$ 1,1 miliar dan sisanya Venezuela akan menjual obligasinya melalui vulture plan. Permasalahannya kemudian sanksi lanjutan Executive Order 13.692 yang dikeluarkan oleh Trump menyusahkan keberadaan vulture investor di Venezuela. Hal ini kemudian dimanfaatkan oleh Venezuela untuk melakukan diplomasinya dengan ALBA karena merasa Amerika Serikat melakukan cara lain untuk menghancurkan perekonomian Venzuela (Thomas 2017).

Selanjutnya dalam pertemuan khusus dewan permanen OAS di New York pada 5 Mei 2016. Delcy Rodriguez sebagai satusatunya perwakilan Venezuela yang hadir dalam pertemuan tersebut menyampaikan pidatonya yang mengklaim bahwa ancaman dan bentuk intervensi yang dilakukan oleh Amerika Serikat bertujuan untuk menjatuhkan pengaturan konstitusi dan proses demokrasi 
Venezulea. Delcy menjelaskan kondisi yang terjadi di Venezuela tidak sesuai dengan apa yang digambarkan dalam media masa internasional. Contohnya media masa Washington Post secara eksklusif memberitakan krisis Venezuela selama 30 hari penuh. Delcy juga mengingatkan kepada negara yang hadir pada tahun 2008 ketika Amerika Serikat melancarkan agresi finansial dengan menyebarkan asumsi di media masa bahwa pemerintah Venezuela tidak dapat mereduksi jumlah masyarakat yang kelaparan, padahal kenyataannya Venezuela telah mereduksi besar-besaran terhadap jumlah masyarakat kelaparan sebagaimana hal tersebut juga diakui oleh PBB dan FAO (Ministerio del Poder Popular Para Relaciones Exteriores 2016).

Poin penting selanjutnya yang dilakukan Venezuela dalam menaikkan balance of fear negara ALBA adalah klaim Venezuela yang menyatakan bahwa Amerika Serikat lah yang berada di balik dari peningkatan kekerasan politik pihak 'kanan' dengan memberikan bantuan dana cukup besar. Strategi balance of fear semakin mudah dilakukan oleh Venezuela ketika Amerika Serikat mengeluarkan ancaman intervensi militer pada tahun 2017. Dalam pertemuan luar biasa Dewan Politik ALBA pada 25 Agustus 2017, Maduro menyatakan bahwa sudah bukan hal yang asing bagi ALBA jika Amerika Serikat akan melakukan intervensi militer di negara-negara Amerika Latin dan Karibia dikarenakan sumber daya alam yang melimpah terutama di Venezuela dengan fakta bahwa Venezuela masih menjadi pemasok utama dalam ALBA (TeleSUR 2017). Selain itu dalam wawancara khusus yang dilakukan di Moscow, Maduro menyatakan bahwa Trump harus paham jika ancaman intervensi militer ini bukan lelucon belaka. Hal ini dikarenakan selain tidak memiliki kekuatan militer yang sebanding dengan Amerika Serikat, ancaman intervensi militer ini akan mengganggu stabilitas keamanan di Venezuela bahkan negara-negara ALBA lainnya (PBS News Hour 2017).

Terakhir, Venezuela mengklaim adanya langkah agresif Amerika Serikat dalam menyikapi krisis Venezuela.Maduro tidak dapat memungkiri bahwasannya, sanksi finansial yang dibebankan Trump kepada Venezuela justru membuat Venezuela lebih independen dan kemungkinan keluar dari krisis ekonomi jauh lebih besar (Ulmer dan Lawder, 2017).Akan tetapi pemberian sanksi tersebut juga berdampak pada Kuba dan Nikaragua yang merupakan aliansi terkuat Venezuela di kawasan tersebut.Kuba dan Nikaragua mendapatkan tekanan dari Amerika Serikat untuk melengserkan pemerintahan 
Sosialis kedua negara tersebut. Menurut Maduro cara Amerika Serikat tersebut merupakan refleksi dari keberlanjutan proses imperialisme. Hal ini dikarenakan jika Amerika Serikat berhasil melengserkan pemerintahan sosialis di Venezuela, Kuba dan Nikaragua maka selanjutnya akan mudah bagi Amerika Serikat untuk memberikan pengaruhnya dan mengontrol setiap negara di kawasan Amerika Latin dan Karibia (Koerner 2017).

\section{Strategi Venezuela dalam Meningkatkan Bandwagoning terhadap Negara ALBA untuk Mempertahankan Eksisten- si Diskursus Suportif}

Dalam meningkatkan bandwagoning terhadap negara anggota ALBA, Venezuela selalu melakukan proses diplomasi yang menekankan hasil kerjasama positif ALBA dan PETROCARIBE. Maduro dalam proses diplomasinya juga kerap membandingkan keberhasilan program sosial yang dijalankan oleh kerjasama ALBA dan PETROCARIBE dengan program OAS yang menurut Maduro cukup kontras. Layaknya sikap diam OAS terkait pemberontakan di Guatemala (1954), Republik Dominika (1966) dan kasus intervensi Amerika Serikat di Kuba (1961), bahkan OAS juga mengabaikan hak asasi masyarakat indigenous di Honduras, Mexico dan Kolombia yang merupakan sekutu Amerika Serikat. Hal tersebut berbanding terbalik dengan sikap Venezuela yang selalu responsif dalam permasalahan apapun yang terjadi di Kawasan (Granma 2017).

Selanjutnya, Venezuela menekankan agresifitas media Barat mengenai krisis Venezuela dan permasalahan domestik di negara lainnya telah mendiskreditkan proses revolusi Bolivarian. Delcy Rodriguez, menilai bahwa media berperan penting dalam proses power-sharing di suatu negara, namun tidak adanya regulasi khusus dalam badan organisasi multilateral yang mengatur peran media pada sistem internasional, membuat negara-negara ALBA sering kali ditempatkan pada posisi yang serba salah karena negara bisa saja dalam suatu kondisi tidak dapat melakukan pembelaan kepada dirinya sendiri. Pemerintah Venezuela mencoba melakukan proses diplomasi kepada masyarakat internasional melalui media masa TeleSUR. Akan tetapi, TeleSUR kemudian masih dianggap oleh media Barat sebagai sarana propaganda karena dinilai tidak menampilkan fakta sesungguhnya kondisi Venezuela, padahal kenyataannya TeleSUR telah menampilkan fakta yang sesungguhnya (TeleSUR TV 2016). 
Selain itu dalam strategi peningkatan bandwagoning, Venezuela juga meminta negara-negara ALBA bertindak sebagai mediator dari proses dialog antara Venezuela dengan Amerika Serikat dan pihak oposisi. Bersama Amerika Serikat dalam beberapa pidatonya Maduro mengakui bahwa Venezuela sudah pernah meminta Amerika Serikat untuk melakukan dialog secara bilateral dengan menujuk Diosdado Cabello sebagai ketua delegasi komsi dialog semenjak tahun 2014 namun tidak dihiraukan. Sedangkan dengan pihak oposisi, negara-negara ALBA diminta menjadi mediator karena melihat ALBA bukanlah aktor eksternal dalam politik domestik Venezuela melainkan sebuah satu kesatuan yang kuat karena adanya integrasi lanjut dalam kawasan. Keterlibatan ALBA dalam proses dialog ini juga dapat meningkatkan bargaining position negara-negara anggota ALBA yang didominasi oleh negara kecil dalam sistem internasional (ALBA-TCP 2015).

Peningkatan solidaritas berdasar sejarah kemerdekaan Amerika Latin terutama sejarah perjuangan Ayacucho dan Simon Bolivar merupakan salah satu strategi dalam meningkatkan bandwagoning kawasan. Seperti halnya dalam pidato maduro yang mengatakan solidaritas ditingkatkan dengan mengutamakan prinsip kebebasan didalamnya, sebagaimana pahlawan-pahlawan seperti Bolivar dan Ayacucho telah membebaskan dan memberikan semangat kemerdekaan kepada masyarakat Amerika Latin (ALBA-TCP, 2015). Menteri Luar Negeri Venezuela (pada tahun 2017), Jorge Arreaza dalam pidatonya juga menilai bahwa perjuangan ALBA saat ini sama dengan yang terjadi pada era perjuangan Ayacucho dan Simon Bolivar yaitu melawan imperialisme dari negara Barat. Maka disini penting bagi ALBA untuk tidak mengulang kesalahan yang sama (Granma 2017).

Terakhir yaitu diselenggarakannya We are all Venezuela day yang merupakan strategi peningkatan bandwagoning melalui proses pergerakan sosial. Venezuela mengadakan pertemuan tingkat tinggi internasional di Caracas pada 16 hingga 19 September dengan 197 delegasi untuk menunjukkan kepada dunia bahwa tidak hanya Venezuela saja yang menolak intervensi pihak imperial melainkan seluruh masyarakat dunia. Maduro menjelaskan bahwa inti dari pertemuan ini menyatakan solidaritas dengan menempatkan posisi sebagai masyarakat Venezuela. Oleh karena itu dalam proses nya, delegasi yang hadir membentuk beberapa inisiatif kampanye internasional baik itu secara langsung maupun jaringan media sosial yang dapat diungkapkan melalui berbagai bahasa (TeleSUR 2017). 


\section{Strategi Agregasi Power Venezuela dalam ALBA untuk Mencegah Terjadinya Defection dalam Kawasan}

Strategi agregasi power yang dilakukan Venezuela adalah melalui peningkatan kerjasama ALBA dengan PETROCARIBEuntuk mengembangkan proyek kawasan di bidang sosial. Tujuannya adalah untuk memudahkan dalam meningkatkan pembangunan sosial di negara-negara kawasan (terutama ALBA), menciptakan kemandirian perekonomian negara-negara Karibia, penguatan pertukaran budaya dan kerjasama lingkungan. Badan pengaturan PETROCARIBE memiliki mekanisme kerjasama yang lebih besar daripada menjaga keamanan pasokan energy. Karena usaha yang dilakukan oleh PETROCARIBE bertujuan untuk mengangkat jutaan manusia yang tinggal di 14 negara untuk keluar dari penderitaan, sehingga sifat PETROCARIBE ini jauh lebih humanistik, lebih dekat dan menghormati masyarakat. Oleh karena itu PETROCARIBE bukan hanya sekedar sarana diplomasi minyak Venezuela saja melainkan sebagai Zona Ekonomi baru di Amerika Latin (Caribflame 2015).

Dalam mewujudkan Zona Ekonomi baru, Venezuela kemudian menandatangani beberapa perjanjian energi dan sosial dalam pertemuan luar biasa ke-4 Dewan Politik ALBA pada 10 Agustus 2015 yang sudah memiliki pendanaan finansial dari inisiatif korporasi energi PETROCARIBE dan Bank of ALBA. Maduro menyebutkan beberapa proyek telah ditandatangani antara lain yaitu: (1) membangun konstruksi energi angin dengan kapasitas produksi 1,5 megawatt; (2) pembangunan klinik kesehatan dan perbaikan produksi pada sektor agrikultur di Dominika; (3) memasang panel solar di beberapa sekolah umum dan konstruksi perumahan di St. Kitts dan Nevis; (4) membangun dan rehabilitasi sekolah di Grenada dan membangun gedung olahraga di St. Vincent dan Grenadines serta membangun rumah bagi tunawisma di St. Lucia. Pembangunan fasilitas-fasilitas ini juga bertujuan untuk meningkatkan kualitas hidup dari negara-negara Karibia, sebagaimana menurut Maduro setiap orang memiliki hak untuk mengembangkan diri dan secara bersama-sama pembangunan akan dicapai (Escambray 2015).

Laporan dari FAO pada tahun 2016, ALBA dan PETROCARIBE tercatat telah berhasil mengembangkan proyek kawasan yang diinisiasi oleh Venezuela terutama di negara-negara Karibia. Pertama dapat dilihat dari Antigua dan Barbuda, semenjak Juni 2015 Petroleos de Venezuela Caribe Antigua y Barbuda (PDVCAB) bekerjasama 
dengan ALBA Caribe Fund mengembangkan projek yang bergerak di area ketahanan pangan antara lain yaitu: (1) People's Benefit Program, yang bertujuan untuk membantu keluarga miskin memenuhi kebutuhan pangan dan produksi pangan untuk menciptakan kualitas hidup lebih baik. Program ini memberikan subsidi sekitar US\$ 80 kepada setiap keluarga dengan pendapatan ratarata kurang dari US\$ 300; (2) rehabilitasi pada tanaman desalinasi di Crabbes (wilayah Antigua) dan Barbuda yang bertujuan untuk memperbaiki kualitas air, mereduksi dan memperluas jaringan distribusi termasuk diantaranya peningkatan jumlah bantuan US\$ 8 juta pada tahun 2015; (3) yaitu meningkatkan peran anak muda dalam bidang agrikultur, tujuan dari program ini adalah untuk memperluas lapangan pekerjaan serta meningkatkan program agrikultur (FAO 2016).

Terdapat tiga proyek utama PETROCARIBE dan ALBA di Dominika yang memberi keuntungan cukup besar adalah: (1) Waitukubuli LPG merupakan tempat pengisian bahan bakar dan pabrik distribusi yang terletak di desa Jimmit dengan kapasitas sekitar 38 MDB. Pabrik ini dibangun oleh PETROCARIBE untuk mengembangkan pasar lokal Dominika terutama untuk memenuhi kebutuhan gas pada beberapa sektor yang membutuhkan; (2) pembangunan program untuk masyarakat Kalinago Caribbean dengan memberikan kredit pinjaman untuk proses pengembangan pertanian. Hingga pada tahun 2016, FAO mencatat terdapat sekitar 2000 kredit yang diberikan oleh ALBA kepada masyarakat di wilayah tersebut; (3) mengembangkan proyek pertenakan dengan membangun produksi unggas dan babi seta menciptakan lahan budi daya ikan (FAO 2016).

Adapun beberapa program pembangunan sosial yang dibangun oleh Venezuela di Grenada khususnya adalah sebagai berikut. Pertama yaitu School Feeding Program (SFP) yang telah beroperasi semenjak tahun 2008. Hingga tahun 2016, sekitar US\$ 1,1 juta telah diimplementasikan dalam pembangunan taman kanak-kanan, sekolah dasar hingga pemasokan gratis makanan gratis bagi pelajar. Selain meningkatkan potensi sumber daya manusia di Grenada, SFP telah memberbaiki pengetahuan produksi makanan lokal, misalnya pemberian informasi tetang nutrisi makanan; mempromosikan pengimplementasian tanaman sayur sekolah, serta membantu pembangunan infrastruktur dan peralatan dasar sekolah. Kedua, Farm Labour Support Program (FLSP) yaitu bertujuan untuk meningkatkan lapangan pekerjaan di bidang pertanian 
dan meningkatkan produksi makanan lokal seperti coklat dan pala. FAO membuktikan bahwa dari tahun 2012 hingga 2016, program ini telah memperluas sekitar 890 hektar untuk lahan pertanian termasuk diantaranya 607 hektar tanaman coklat, 141,6 hektar pala, dan 51,4 hektar buah-buahan. Ketiga, program Hugo Chavez LPG Cylinder Filling Plant yang merupakan program kerjasama keamanan energi dan dibentuk karena adanya gabungan kepemilikanantara perusahaan PDV Grenada Ltd. dengan PETROCARIBE. Semenjak pertama kali dibentuk pada tahun 2015, Venezuela telah menginvestasikan sekitar US\$ 3,9 juta untuk memenuhi kapasitas cadangan minyak sekitar 1200 barrels (FAO 2016).

Nikaragua merupakan negara yang paling bergantung dengan Venezuela melalui program ALBA dan PETROCARIBE, hal ini dapat dilihat dari banyaknya program pembangunan sosial antara lain. Pertama yaitu Zero Usury yang bertujuan untuk memberikan kesempatan bagi wanita agar mendapatkan pekerjaan dan dapat mengakses sistem fiansial internasional. Dalam hal ini terdapat sekitar peminjaman dana sekitar 137 hingga US\$ 367 dengan bunga rendah yang diberikan kepada janda yang sumber perekonomiannya bergantung pada bisnis kecil-kecilan. Terdapat sekitar 39.96 juta antara 2007 hingga 2015 dan sekitar 66,786 wanita yang mendapatkan manfaat positif dari program kerjasama. Kedua yaitu "Christian, Socialist and Solidary" Special Plan for the Production of Basic Grains (CRISSOL) yang sebenarnya memiliki metodologi dari program Zero Usury tapi dengan pihak manapun bebas terlibat. Total investasi yang dilakukan Venezuela dan ALBA sekitar US\$ 36.07. Ketiga Food Program for the People yang merupakan program di bawah tanggung jawab ENABAS bertujuan untuk menjamin akses makanan pokok, jagung, kacang, beras, gula dan minyak dengan harga yang seadilnya dan dikhususkan pada keluarga miskin. Supply dilakukan dengan melalui 3,817 jaringan distribusi baik itu didaerah perkotaan dan pedesaan. Antara tahun 2007 hingga 2016, FAO menjelaskan bahwa sekitar 236,842 warga yang mendapatkan manfaatnya dan per tahun 2015, ALBA Caribe Fund telah meningkatan nilai investasi sebesar 120.89 juta (FAO 2016).

Terakhir, yaitu St. Vincent dan Grenadines. Titik balik meningkatnya kerjasama antara St. Vincent dan Grenadines dengan Venezuela adalah ketika terjadinya penurunan ekspor agrikultur ke Inggris dan negara-negara Eropa lainnya. St. Vincent dan Grenadines yang bekerjasama dengan PETROCARIBE dan Venezuela mendirikan 
Farmers Support Company Ltd. (FSC) yang bertujuan untuk memberikan pinjaman kepada petani dengan tingkat bunga 2\% agar petani dapat melakukan akusisi supply hasil pertanian dan pembayaran tenaga kerja pertanian dalam proses produksi lahan. Total petani yang teregistrasi pada akhir 2014 hingga awal 2015 mencapai 6500 dan produksi pertanian yang dibiaya antara lain pisang raja, singkong, kentang manis, garut dan cabai selain itu termasuk juga ternak sapi dan kambing. Dampak yang dihasilkan kurang lebih 313 wanita dan 49 anak muca di usia 18 hingga 35 tahun memiliki pekerjaan. Kedua, kerjasama ketahanan energi melalui Hugo Chavez Fuel Storage and Distribution Plant yang dimulai pada April 2015 dengan Venzuela memasok 34 ribu barel minyak dan dua tank LPG dengan kapasitas seribu barel sekali isi. Adapun tank ini bertujuan sebagai bagian proses distribusi gas rumah tangga dengan harga yang lebih murah (FAO 2016).

Tidak cukup sampai disitu, pada tahun 2015 Venezuela menggandeng Food Agricultural Organization (FAO) untuk bekerjasama dengan ALBA dan PETROCARIBE membentuk program Seguridad $y$ Soberania Alimentaria y Nutricional Para America Latina y El Caribe (SANA) pada tahun 2015. SANA merupakan program kerja sama triangular dalam bidang ketahanan pangan dan kebutuhan nutrisional. SANA mendukung Hugo Chavez Action Plan untuk mengurangi tingkat masyarakat kelaparan dan kemiskinan, meningkatkan pergerakan sosial dan membentuk pertukaran komplementer pangan dan produk pangan negara Amerika Latin dan Karibia. Venezuela dalam hal ini tidak hanya mengimplementasikan highimpact initiatives, melainkan menempatkan diri sebagai partner utama dalam beberapa program South-South Cooperation yang bertujuan untuk mencapai perdamaian dalam membebaskan kelaparan dari masyarakat Amerika Latin dan Karibia. Kepercayaan diri Venezuela dalam mengemban program tersebut tidak hanya disebabkan oleh posisinya sebagai negara dengan pendapatan yang cukup tinggi di kawasan tersebut namun Venezuela telah melampaui standar Millenium Development Goal (MDG) dalam bidang kelaparan dengan berhasil menurunkan tingkat kelaparan di kawasan Amerika Latin sebesar 5\% melalui peningkatan integrasi kawasan dan kerjasama internasional (FAO 2015).

\section{Simpulan}

Penelitian ini menyimpulkan bahwa untuk melawan tekanan Amerika Serikat, Venezuela yang juga berada dalam krisis ekonomi dan kemanusiaaan menerapkan tiga strategi kooperatif hegemoni 
terhadap negara-negara yang tergabung dalam ALBA antara lain: reduksi balancing dengan negara anggota ALBA melalui balance of fear terhadap Amerika Serikat, peningkatan bandwagoning untuk mempertahankan eksistensi diskurs suportif negara ALBA dan agregasi power Venezuela dalam ALBA. Pertama yaitu strategi reduksi balancing melalui peningkatan balance of fear, adapun strategi ini kemudian menimbulkan stigma negatif dari negara anggota ALBA dan memicu adanya penolakan terhadap setiap sanksi yang diberikan Amerika Serikat kepada Venezuela. Kedua yaitu strategi peningkatan bandwagoning, stategi peningkatan bandwagoning yang dilakukan oleh Venezuela melalui proses power-sharing dengan menekankan lima prinsip utama kawasan yaitu solidaritas, komplementaritas, untuk mencapai keuntungan bersama, anti-imperialisme dan berorientasi pada ideologi sosialis. Ketiga yaitu strategi agregasi power Venezuela, dalam strategi tersebut Venezuela menekankan adanya pencapaian regional public goods. Regional public goods yang dimaksud dalam proyek ALBA disini adalah proyek-proyek kawasan yang diciptakan untuk mencapai final goods yaitu kesetaraan global, menurunkan angka kemiskinan kawasan dan terciptanya perdamaian dengan negara-negara dominasi.

Dalam mempertahankan diri dari tekanan eksternal, Venezuela yang menggunakan strategi kooperatif hegemoni berhasil mendapatkan dukungan dari negara kawasan. Sebagaimana Venezuela selalu menolak sebutan krisis kemanusiaan dan menyatakan bahwa Amerika Serikat menyebabkan krisis ekonomi yang terjadi sehingga kekerasan politik domestik Venezuela meningkat semenjak pemberontakan yang terjadi pada pemerintahan Hugo Chavez tahun 2002. Venezuela disini juga memanfaatkan posisinya sebagai regional power yang mengalami krisis untuk mendapatkan dukungan dari negara-negara ALBA dan menekankan pentingnya kedaulatan negara agar negara-negara dunia tetap menghormati rezim pemerintahan Maduro. Selain itu, strategi Venezuela ini dapat dengan mudah diterapkan karena negara-negara ALBA kebanyakan juga mengalami pertentangan dengan Amerika Serikat dan cukup skeptis terhadap keberadaan OAS sendiri, misalnya Kuba, Nikaragua dan negara-negara Karibia lainnya. Adanya pertentangan antara negara-negara ALBA lainnya dengan Amerika Serikat ini juga dipicu oleh sikap agresifitas Amerika Serikat dalam menyikapi pemerintah kiri di Amerika Latin sebagai bentuk balance of power terhadap keberadaan Tiongkok dan Rusia. 


\section{Daftar Pustaka}

\section{Buku}

Harris, David dan Diego Azzi. 2004. ALBA Venezuela's Answer to "Free Trade": the Bolivarian Alternative for the Americas. Sao Paulo: Alianza Social Continental, hlm. 5-16

\section{Jurnal dan Jurnal Daring}

Pedersen, Thomas. 2002. "Cooperative Hegemony: Power, Ideas and Institutions in Regional Integration", dalam Review of International Studies, Vol. 28, No. 4 (Oct., 2002), hlm. 677-696

\section{Artikel Daring}

Al Jazeera. 2017. Delcy Rodriguez: No humanitarian crisis in Venezuela. Tersedia dalam: http://www.aljazeera.com/programmes/ talktojazeera/2017/09/delcy-rodriguezhumanita -rian-crisisvenezuela-170907060655166.html [diakses 9 Oktober 2017].

ALBA-TCP. 2015. Declaration of the IX Extraordinary ALBA-TCP Summit [Online]. Tersedia dalam:www.portalalba.org/declaracion-de-la-ix-cumbre-extraordinaria-del-alba-tcp/ [diakses 22 Desember 2017].

Caribflame. 2015. In 10 years Petrocaribe transformed economic and social situation of the region [Online]. Tersedia di dalam http://www.caribflame.com/2015/o7/in-10-years-petrocaribe-transformed-economic-and-social-situation-of-the-region/ [diakses 1 Mei 2018].

Casey, Nicolas. 2017. Trump's Threat Against Maduro Unites Latin America, Against U.S. [Online]. Tersedia dalam: https://www. nytimes.com/2017/o8/14/world/americas/trump-venezuelamaduro-latin-america.html [diakses 28 Februari 2018].

Escambray Cuba. 2016. Raul Castro: Supporting Venezuela Means Fighting for Latin American and Caribbean Emancipation [Online]. Tersedia dalam: http://en.escambray.cu/2016/raul-castro-supporting-venezuela-means-fighting-for-latin-americanand-caribbean-emancipation/ [diakses 15 April 2018]. 
FAO. 2015. SANA will support the Hugo Chávez Action Plan for the Eradication of Hunger and Poverty, strengthen social movements and create the complementary exchange of food and food products [Online]. Tersedia dalam: http://www.fao.org/americas/noticias/ver/en/c/283757/ [diakses 2 Mei 2018]

Granma. 2017. Unity to strengthen ALBA [Online]. Tersedia dalam: http://en.granma.cu/mundo/2017-03-07/unity-to-strengthenalba [diakses 1 Mei 2018].

Koerner, Lucas. 2017. Venezuelan Opposition Backs US Sanctions amid International Condemnation [Online]. Tersedia dalam: https://venezuelanalysis.com/news/13333 [diakses 15 Februari 2018].

Ministerio del Poder Popular Para Relaciones Exteriores. 2015. President Maduro published a letter in today's NYT to the people of the US: "Venezuela is not a Threat" [Online]. Tersedia dalam: http://eeuu.embajada.gob.ve/index.php?option=com content\&view $=$ article\&id=385\%3Acarta-publicada-hoy-en-elnew-york-times-para-el-pueblo-de-los-estados-unidos-venezuela-no-es-una-amenaza\&catid $=2 \% 3$ Anoticias-de-venezuela-eneeuu\&Itemid =18\&lang=en [diakses 19 Desember 2017]

. 2016. Foreign Minister Rodriguez demonstrated the truth of Venezuela at the OAS [Online]. Tersedia dalam: http:// eeuu.embajada.gob.ve/index.php?option $=$ com_content\&view $=$ article\&id $=554 \% 3$ Acanciller-rodriguez-demostro-la-verdadde-venezuela-en-la-oea-\&catid=2\%3Anoticias-de-venezuela-eneeuu\&Itemid=18\&lang=en [diakses 23 Februari 2018].

National Archives. 2015. Executive Order-Blocking Property and Suspending Entry of Certain Persons Contributing to the Situation in Venezuela [Online]. Tersedia dalam: obamawhitehouse. archives.gov/the-press-office/2015/03/o9/executive-orderblocking-property-and-suspending-entry-certain-persons-c [diakses 13 Februari 2018].

PBS News Hour. 2017. Maduro: Trump has 'no right' to joke about military action in Venezuela (Video File Online). Tersedia dalam: https://www.pbs.org/newshour/show/maduro-trumpno-right-joke-military-action-venezuela [diakses 31 Maret 2018]. 
Pedersen, Thomas. 2002. "Cooperative Hegemony: Power, Ideas and Institutions in Regional Integration", dalam Review of International Studies, Vol. 28, No. 4 (Oct., 2002), hlm. 677-696.

Pedraza, David Gracia. 2016. OAS Calls for Wider and Stronger Sanctions Against Venezuela [Online]. Tersedia dalam: https:// www.latinamericanpost.com/index.php/international-relations-latam/19811-oas-calls-for-wider-and-stronger-sanctionsagainst-venezuela [diakses 13 Februari 2018].

TeleSUR. 2015. US Has Budgeted \$49M for Venezuelan RightWing Since 2009 [Online]. https://www.telesurtv.net/english/ news/US-Has-Budgeted-49M-for-Venezuelan-Right-WingSince-2009-20170517-0018.html [diakses 22 Mei 2018].

. 2016. Maduro Warns of New US-Backed 'Plan Condor' Against Left Govts [Online]. Tersedia dalam: https:// www.telesurtv.net/english/news/Maduro-Warns-of-New-USBacked-Plan-Condor-Against-Left-Govts-20160518-0011.html [diakses 23 Februari 2018].

. 2017. 86\% of Venezuelans Reject Foreign Military Intervention [Online]. Tersedia dalam: https://www.telesurtv.net/ english/news/86-of-Venezuelans-Reject-Foreign-Military-Intervention-20170815-0025.html [diakses 13 Februari 2018].

.2017. Global Leaders Celebrate World Solidarity Day With Venezuela [Online]. Tersedia dalam: https://www.telesurtv.net/ english/news/Global-Leaders-Celebrate-World-Solidarity-DayWith-Venezuela-20170916-0003.html [diakses 1 Mei 2018].

Thomas Jr., Landon. 2017. Venezuelan Debt Now Has the Vultures Circling [Online]. Tersedia dalam: https://www.nytimes. com/2017/11/14/business/venezuela-debt-investors.html [diakses 27 Mei 2018].

Ulmer, Alexandra dan David Lawder. 2017. Trump slaps sanctions on Venezuela; Maduro sees effort to force default [Online]. Tersedia dalam: https://www.reuters.com/article/us-usa-venezuela-sanctions/trump-slaps-sanctions-on-venezuela-madurosees-effort-to-force-default-idUSKCN1B5216 [diakses 13 Februari 2018].

White House. 2017. Presidential Executive Order on Imposing Sanctions with Respect to the Situation in Venezuela [Online]. 
Tersedia dalam: https://www.whitehouse.gov/presidential-actions/presidential-executive-order-imposing-sanctions-respectsituation-venezuela/ [diakses 28 Februari 2018].

Worstall, Tim. 2016. Congratulations to Venezuela - IMF Predicts Inflations of 1,600\% in 2017 [Online]. Tersedia dalam: https:// www.forbes.com/sites/timworstall/2016/07/19/congratulations-to-venezuela-imf-predicts-inflation-of-1600-in-2017/ [diakses 11 Mei 2017].

\section{Lain-lain}

FAO. 2016. PETROCARIBE: 10 Years of Struggle Against Hunger and Poverty (Online pdf) Tersedia dalam: www.fao.org/3/ai4918e.pdf [diakses 30 April 2018].

TeleSUR TV. 2016. ALBA-TCP se solidariza con Venezuela ante ataques de derecha mundial (Video File Online). Tersedia dalam: https://videos.telesurtv.net/video/555235/alba-tcp-sesolidariza-con-venezuela-ante-ataques-de-la-derecha-mundia/ [diakses 15 April 2018]. 